We wish to thank the medical staff at University College Hospital, the Royal Free Hospital, the Middlesex Hospital Charing Cross Hospital, and Guy's Hospital for allowing us to study patients under their care, and Miss Keena Jones and Mrs. Eva Goldenberg for conducting the interviews. We are grateful also to the Medical Research Council, under whose auspices this work was begun when two of us (M.P.V. and R.D.) were members of the Council's Statistical Research Unit, and which continues to employ Miss Jones and Mrs. Goldenberg.

\section{References}

Allen, W. (1969). Cancer (Philadelphia), 24, 1137.

Arthes, F. G., Sartwell, P. E., and Lewison, E. F. (1971). Cancer (Philadelphia), 28, 1391.

Brown, J. M. (1970). Medical Fournal of Australia, 1, 276.

Burns-Cox, C. J., Doll, R., and Ball, K. P. (1969). British Heart fournal, 31, 485.

Doll, R. (1970). Fournal of Biosocial Science, 2, 367.
Fechner, R. E. (1970a). American fournal of Clinical Pathology, 53, 857.

Fechner, R. E. (1970b). Cancer (Philadelphia), 25, 1332.

Fechner, R. E. (1970c). Cancer (Philadelphia), 26, 1204.

Garcia, C. R., Pincus, G., Rocamora, H., and Wallach, E. E. (1965). In Proceedings of the VI Pan-American Congress of Endocrinology, p. 138. Amsterdam, Excerpta Medica.

Goldenberg, V. E., Wiegenstein, L., and Mottet, N. K. (1968). American Fournal of Clinical Pathology, 49, 52.

Hertz, R. (1969). Cancer (Philadelphia), 24, 1140.

Kay, C. R. (1970). Fournal of the Royal College of General Practitioners, 19,

Leis, H. P. (1970). New York State fournal of Medicine, 70, 2911.

Lowe, C. R., and MacMahon, B. (1970). Lancet, 1, 153.

, M. C., and Morrow, R. H. (1970). British fournal of Preventive and Social Medicine, 24, 42.

Shapiro, S., Strax, P., Venet, L., and Fink, R. (1968). American fournal of Public Health, 58, 820

Valaoras, V. G., MacMahon, B., Trichopoulos, D., and Polychronopoulou, A. (1969). International fournal of Cancer, 4, 350 .

Vessey, M. P. (1970). M.D. thesis, University of London

Vessey, M. P. (1971). American fournal of Epidemiology, 94, 202.

Vessey, M. P., Doll, R., and Sutton, P. M. (1971). Cancer (Philadelphia), 28, 1395.

Zippin, C., and Petrakis, N. L. (1971). Cancer (Philadelphia), 28, 1381.

\title{
Daily Requirement of Oxygen to Reverse Pulmonary Hypertension in Patients with Chronic Bronchitis
}

\author{
R. D. STARK, P. FINNEGAN, J. M. BISHOP
}

British Medical fournal, 1972, 3, 724-728

\section{Summary}

We have shown previously in patients with chronic bronchitis that correction of the hypoxaemia by continuous administration of oxygen substantially reduced the pulmonary hypertension by reversal of structural changes in the pulmonary resistance vessels. We have now demonstrated that such improvements may occur with less than continuous oxygen. Treatment with oxygen for 18 hours daily significantly decreased pulmonary arterial pressure and pulmonary vascular resistance. Oxygen therapy for 15 hours a day also decreased pulmonary vascular resistance; such a regimen is practicable in the home, is consistent with a working day free from the constraints of an oxygen supply, and should reduce the number of episodes of congestive cardiac failure.

\section{Introduction}

Patients who are chronically hypoxaemic because of chronic bronchitis frequently develop pulmonary hypertension. This leads to right ventricular hypertrophy and right ventricular failure. In these patients the cardiac failure becomes a major part of their disability, and its presence carries a particularly. poor prognosis. Of a large series of patients with chronic bronchitis studied by Renzetti, McClement, and Litt (1966) $53 \%$ died within four years. Those in the group who had a history of congestive cardiac failure suffered a mortality of $73 \%$ in the same period. Ude and Howard (1971) found that $68 \%$ of patients with chronic bronchitis who had survived their first episode of congestive cardiac failure died within the next five years. A similar figure was reported at the same centre 14 years earlier by Stuart-Harris and Hanley (1957). Since antibiotics and powerful diuretics have failed to improve the prognosis a

Department of Medicine, University of Birmingham, Queen Elizabeth Hospital, Birmingham 15

R. D. STARK, M.B., PH.D., Research Fellow

P. FINNEGAN, M.B., M.R.C.P., Lecturer in Medicine

J. M. BISHOP, M.D., P.R.C.P., Professor of Medicine more promising approach may be to attempt to prevent congestive cardiac failure by reduction of the pulmonary hypertension; the analogy with systemic hypertension is obvious.

The structural basis for the pulmonary hypertension has been shown by Hicken, Heath, Brewer, and Whitaker (1965) and Hasleton, Heath, and Brewer (1968) to be a pattern of changes in the pulmonary arterioles and small pulmonary arteries unique to conditions associated with chronic hypoxaemia. The media of the arterioles is thickened by the deposition of circular smooth muscle, and longitudinal bundles of muscle appear in the intima of the arterioles and small arteries.

In 1968 Abraham, Cole, and Bishop reported on six hypoxaemic patients in the late phase of chronic bronchitis in whom episodes of right heart failure had occurred. Right heart catheterization confirmed that pulmonary hypertension was present. The hypoxaemia was then corrected for periods of four to eight weeks by continuous administration of oxygen in an inspired concentration of about $30 \%$. Pulmonary arterial pressure and pulmonary vascular resistance decreased significantly. Similar responses to continuous oxygen were reported by Levine et al. (1967).

The measurements of pulmonary arterial pressure were made after the patients had been breathing air for two hours. Thus the decrease in pulmonary arterial pressure was not an acute response dependent on a raised oxygen tension but was an effect lasting many hours. When the oxygen therapy was finally discontinued there was a gradual rise in pulmonary arterial pressure over a period of weeks (Abraham et al., 1968). These responses would be consistent with the following explanation.

Hypoxaemia due to chronic bronchitis leads to a structural change in the pulmonary arterioles and small arteries, and this change maintains the pulmonary hypertension. Correction of the hypoxaemia by continuous oxygen therapy leads to regression of the structural change in the pulmonary vessels and reversal of the pulmonary hypertension. Histological study of the pulmonary vessels before and after oxygen treatment is not possible in man but studies on rats have shown that similar structural changes occurred in the small pulmonary arteries while the rats were in a hypoxic environment (Abraham, Kay, Cole, and Pincock, 1971). These changes reversed when the oxygen tension was returned to normal. 
The present study was concerned with the application of the above findings to develop a regimen for long-term treatment of pulmonary hypertension in chronic bronchitis. This was done in the belief that maintained reversal of pulmonary hypertension would prevent episodes of cardiac failure and would therefore diminish the patient's disability and increase his life expectancy. Continuous administration of oxygen while at home and at work presents considerable problems in organization. The first step in the development of a practicable therapeutic regimen was to find the minimum daily requirement of oxygen necessary to reverse the pulmonary hypertension.

\section{Patients and Methods}

Eleven men with long-standing chronic bronchitis took part in the study. It was explained to them before admission to the trial that a new form of treatment was being tested which might benefit them but that no guarantee of success could be given. We emphasized the length of the hospital stay and the need for close monitoring of their response with tests of pulmonary function, determination of red cell volume, and cardiac catheterization. The patients were interviewed again several days after the initial discussion and asked if they wished to enter the trial. Before each investigation the procedure was explained, permission requested, and the patient's willingness was checked independently by the house physician, who was not part of the research team.

The patients were aged 39-67 years and all were hypoxaemic (see Table I). Each patient had experienced at least one episode of right heart failure and most were severely disabled. Before the start of the trial the patients were stabilized on therapy which in most cases included digoxin, frusemide or bendrofluazide, spironolactone, and proxyphylline. No change in the dose of these drugs was made during the period of the study. No patient received corticosteroids. Several patients started to produce purulent sputum during the course of the trial and this was treated promptly with antibiotics. Before the initial investigations were begun the patients were observed for at least one week to ensure that they were free from clinical evidence of respiratory infection and congestive cardiac failure indicated by oedema, raised jugular venous pressure, and an unsteady body weight. Exacerbations of bronchitis may cause a transient rise in pulmonary arterial pressure (Abraham et al., 1969), and therefore care was taken to avoid starting a study in the phase of recovery from a respiratory infection.

All patients had at some time smoked cigarettes regularly, but at the start of the trial only six smoked. Three of these did not change their habits during the period of oxygen therapy (but did not smoke while receiving oxygen) and three reduced their smoking.

\section{RESPIRATORY STUDIES}

Static lung volumes, forced expiratory volume in one second, and single-breath transfer factor for carbon monoxide were measured in the usual way. Arterial oxygen and carbon dioxide tensions were measured by microelectrodes (Radiometer). Oxygen was administered by twin nasal prongs (Pharmaseal nasal catheters) which caused little discomfort and permitted eating, talking, and sleeping. The flow of oxygen for the first night was $11 . / \mathrm{min}$ and thereafter it was increased to $21 . / \mathrm{min}$. The latter is known to supply an inspired oxygen concentration of about $30 \%$ (Green, 1967). A few patients complained of headache in the mornings but this did not continue for more than a few days. The oxygen was not humidified, and although most subjects noted minor nasal irritation in the early weeks of treatment this never persisted. Mobility of the patient was encouraged by the provision of a portable supply of oxygen on a trolley.

\section{CIRCULATORY STUDIES}

Patients underwent right heart catheterization while breathing air at least two hours after stopping oxygen therapy. Thus the reduction in pulmonary arterial pressure which occurred after oxygen therapy was not an acute response dependent on the presence of a higher $\mathrm{PaO}_{2}$, but was a more lasting response which persisted after return of the $\mathrm{PaO}_{2}$ to the usual level for that patient. The studies were performed in the fasting state and without sedation.

A No. 9 double lumen Cournand catheter was passed into the pulmonary artery; pulmonary arterial pressure was transmitted to the pressure transducer through a side hole. In most studies pulmonary wedge pressure was also obtained, but when technical difficulties prevented this it was assumed that the pulmonary wedge pressure did not change from the preceding or succeeding study in that patient. The pulmonary arterial and wedge pressures were measured by transducers (Sanborn model $267 \mathrm{BC}$ ) which recorded on an ultraviolet photographic recorder. Mean pressures were determined by planimetry over several respiratory cycles and were related to a point $5 \mathrm{~cm}$ below the sternal angle.

Cardiac output was measured by the direct Fick method. The oxygen saturation of blood samples from the pulmonary and brachial arteries was determined by a spectrophotometric method. Simultaneously the expired air was collected (rest 3 $\mathrm{min}$, exercise $1 \mathrm{~min}$ ) and analysed by the Scholander method for the measurement of oxygen uptake. These measurements were made at rest and during the fifth minute of supine exercise with a bicycle ergometer. The exercise load was submaximal and adjusted to the fitness of the patient; it was kept unaltered during subsequent studies to minimize changes in oxygen uptake. In some patients the cardiac output varied from study to study, and this affected the pulmonary arterial pressure. To compensate for such changes pulmonary vascular resistance (pressure gradient across the pulmonary vascular bed divided by pulmonary blood flow) was evaluated.

Samples of blood were collected from a peripheral vein without stasis and centrifuged in duplicate in Wintrobe tubes at $2,000 \mathrm{~g}$ for 30 minutes. The measured values for packed cell volume were corrected for trapped plasma by multiplication by 0.96 . Red cell volume was determined by a ${ }^{31} \mathrm{Cr}$ method similar to that described previously (Abraham et al., 1968).

\section{GENERAL}

Patients were studied before oxygen therapy and after three to seven weeks. In some cases an intermediate study was carried out at three weeks. Patients were allocated at random to three treatment groups-18 hours, 15 hours, and 12 hours of oxygen a day. The statistical significance of the difference between the values before and after treatment was measured using Student's $t$ test. Since the hypothesis under test postulated a decrease in pulmonary arterial pressure and pulmonary vascular resistance a single-tailed $t$ test was used for those values.

\section{Results}

\section{LUNG VOLUMES AND BLOOD GAS TENSIONS}

In all patients the forced expiratory volume in one second was less than 1.21. (Table I). The vital capacity was between 1.5 and 3.41 . (mean 2.4 1.) and the residual volume was between 2.0 and $6 \cdot 81$. (mean $4 \cdot 21$.). After the period of oxygen therapy the mean forced expiratory volume in one second was 0.841 . (0.80 1 . before treatment), mean vital capacity $2 \cdot 51$. (2.4 1 . before), and mean residual volume $4 \cdot 31$. (4.2 1 . before). These data confirm our previous findings that ventilatory function did not change significantly during the period of oxygen therapy (Abraham et al., 1968). 
All patients were hypoxaemic while breathing air. The highest $\mathrm{PaO}_{2}$ was $62 \mathrm{~mm} \mathrm{Hg}$ and the mean was $49 \mathrm{~mm} \mathrm{Hg}$ (Table I). Oxygen delivered at $21 . / \mathrm{min}$ raised the mean $\mathrm{PaO}_{2}$ to $70 \mathrm{~mm} \mathrm{Hg}$, the lowest value being $59 \mathrm{~mm} \mathrm{Hg}$. The mean $\mathrm{PaCO}_{2}$ while breathing air was $57 \mathrm{~mm} \mathrm{Hg}$ and this usually rose during oxygen therapy (mean $63 \mathrm{~mm} \mathrm{Hg}$ ). The only clinical feature of carbon dioxide retention which occurred was headache, and this never persisted after the first few days of treatment. Before the period of oxygen therapy the mean $\mathrm{PaO}_{2}$ was $47 \mathrm{~mm} \mathrm{Hg}$ and the mean $\mathrm{PaCO}_{2} 61 \mathrm{~mm} \mathrm{Hg}$. After the period of therapy the mean $\mathrm{PaO}_{2}$ was $52 \mathrm{~mm} \mathrm{Hg}$ and the mean $\mathrm{PaCO}_{2}$ $54 \mathrm{~mm} \mathrm{Hg}$ while breathing air.

\section{OXYGEN ADMINISTRATION 18 HOURS DAILY}

Four patients (control data in Table I) received oxygen for 18 hours daily over a period of six weeks. In all four there was a decrease in packed cell volume; in two red cell volume was measured, and in both patients this decreased (Table II). The mean pulmonary arterial pressure decreased from 51 to 31 $\mathrm{mm} \mathrm{Hg}$, and this reduction was significant $(P<0.05)$. As reported before (Abraham et al., 1968) there was no significant change in cardiac output. The decrease in pulmonary vascular resistance after treatment with oxygen for 18 hours daily was significant $(P<0.05)$. However, Table II and Fig. 1 show that one patient in this group had only a small response in pulmonary arterial pressure and pulmonary vascular resistance.

In Fig. 2 the pulmonary vascular resistance after oxygen therapy is expressed as a percentage of the pulmonary vascular resistance for that patient before treatment with oxygen. This shows clearly that the response to oxygen may increase over a period of six weeks.

The responses to exercise are shown in Table III. The oxygen uptake during steady-state exercise before and after oxygen therapy sometimes differed-for example, in Case 2-

TABLE I-Clinical Data on Patients and Mean Respiratory Values before and after Oxygen Administration

\begin{tabular}{|c|c|c|c|c|c|c|c|c|c|}
\hline \multirow{2}{*}{$\begin{array}{c}\text { Case } \\
\text { No. }\end{array}$} & \multirow{2}{*}{$\underset{\text { (years) }}{\text { Age }}$} & \multirow{2}{*}{$\begin{array}{c}\text { Weight } \\
(\mathbf{k g})\end{array}$} & \multirow{2}{*}{$\begin{array}{c}\text { Body Surface } \\
\text { Arrea } \\
\left(\mathrm{m}^{2}\right)\end{array}$} & \multicolumn{2}{|c|}{$\mathrm{PaO}_{\mathbf{2}}(\mathrm{mmHg})$} & \multicolumn{2}{|c|}{$\mathrm{PaCO}_{2}(\mathrm{mmHg})$} & \multicolumn{2}{|c|}{$\mathrm{FEV}_{1}(1)}$. \\
\hline & & & & On Air & On $\mathrm{O}_{1}$ & On Air & $\mathrm{On} \mathrm{O}_{2}$ & Before $\mathrm{O}_{2}$ & After $\mathrm{O}_{3}$ \\
\hline $\begin{array}{r}1 \\
2 \\
3 \\
4 \\
5 \\
6 \\
7 \\
8 \\
9 \\
10 \\
11\end{array}$ & $\begin{array}{l}48 \\
47 \\
67 \\
63 \\
55 \\
57 \\
39 \\
50 \\
62 \\
64 \\
63\end{array}$ & $\begin{array}{l}40 \\
84 \\
60 \\
68 \\
82 \\
51 \\
86 \\
57 \\
81 \\
91 \\
65 \\
\end{array}$ & $\begin{array}{l}1.36 \\
1.90 \\
1.72 \\
1.80 \\
1.95 \\
1.56 \\
2.14 \\
1.69 \\
1.99 \\
2.10 \\
1.62 \\
\end{array}$ & $\begin{array}{l}43 \\
50 \\
41 \\
51 \\
48 \\
42 \\
45 \\
54 \\
53 \\
50 \\
62\end{array}$ & $\begin{array}{l}66 \\
62 \\
78 \\
66 \\
79 \\
59 \\
60 \\
81 \\
73 \\
68 \\
77\end{array}$ & $\begin{array}{l}60 \\
59 \\
61 \\
43 \\
54 \\
66 \\
50 \\
55 \\
51 \\
69 \\
54\end{array}$ & $\begin{array}{l}74 \\
68 \\
67 \\
39 \\
60 \\
76 \\
45 \\
80 \\
67 \\
61 \\
52\end{array}$ & $\begin{array}{l}0.63 \\
1.17 \\
0.52 \\
0.56 \\
0.99 \\
0.44 \\
0.86 \\
0.51 \\
0.96 \\
1.03 \\
1.15\end{array}$ & $\begin{array}{l}0.59 \\
1.05 \\
0.49 \\
0.90 \\
1.11 \\
0.41 \\
0.19 \\
0.74 \\
0.96 \\
1.13 \\
1.17\end{array}$ \\
\hline Mean & & & & 49 & 70 & 57 & 63 & 0.80 & 0.84 \\
\hline
\end{tabular}

Oxygen was given for three to seven weeks at $21 . / \mathrm{min}$.

$\mathrm{FEV}_{1}=$ Forced expiratory volume in one second.

TABLE II-Pulmonary Haemodynamic and Blood Values before and after Oxygen Administration

\begin{tabular}{|c|c|c|c|c|c|c|c|c|c|c|c|c|c|c|c|}
\hline \multirow{2}{*}{$\begin{array}{c}\text { Case } \\
\text { No. }\end{array}$} & \multirow{2}{*}{$\begin{array}{c}\text { Hours of } \\
\mathrm{O}_{2} / \text { Day }\end{array}$} & \multirow{2}{*}{$\begin{array}{c}\text { No. of } \\
\text { Weeks on } \\
\mathrm{O}_{2}\end{array}$} & \multicolumn{2}{|c|}{ P.A.P. $(\mathrm{mmHg})$} & \multicolumn{2}{|c|}{ P.W.P. (mmHg) } & \multicolumn{2}{|c|}{$\begin{array}{c}\text { Cardiac Output } \\
\text { (1./min) }\end{array}$} & \multicolumn{2}{|c|}{$\begin{array}{l}\text { P.V.R. } \\
\left.\text { (dyn } / \mathrm{sec} / \mathrm{cm}^{-b}\right)\end{array}$} & \multirow{2}{*}{$\begin{array}{c}\text { P.V.R. After } \mathrm{O}_{2} \\
\begin{array}{c}\text { P.V.R. Before } \mathrm{O}_{\mathbf{2}} \\
(\%)\end{array}\end{array}$} & \multicolumn{2}{|c|}{ P.C.V. (\%) } & \multicolumn{2}{|c|}{$\begin{array}{c}\text { Red Cell Mass } \\
(\mathrm{ml} / \mathrm{kg})\end{array}$} \\
\hline & & & $\begin{array}{c}\text { Before } \\
\mathrm{O}_{2}\end{array}$ & $\begin{array}{c}\text { After } \\
\mathrm{O}_{2}\end{array}$ & $\begin{array}{c}\text { Before } \\
\mathrm{O}_{2}\end{array}$ & $\begin{array}{c}\text { After } \\
\mathrm{O}_{2}\end{array}$ & $\begin{array}{c}\text { Before } \\
\mathrm{O}_{2}\end{array}$ & $\begin{array}{c}\text { After } \\
\text { O, }\end{array}$ & $\begin{array}{c}\text { Before } \\
\mathrm{O},\end{array}$ & $\begin{array}{c}\text { After } \\
\mathrm{O}_{2}\end{array}$ & & $\begin{array}{c}\text { Before } \\
\mathrm{O}_{2}\end{array}$ & $\begin{array}{c}\text { After } \\
\mathrm{O}_{2}\end{array}$ & $\begin{array}{c}\text { Before } \\
\mathrm{O}_{2}\end{array}$ & $\begin{array}{c}\text { After } \\
\mathrm{O}_{3}\end{array}$ \\
\hline $\begin{array}{r}1 \\
2 \\
3 \\
4 \\
5 \\
6 \\
7 \\
8 \\
9 \\
10 \\
11\end{array}$ & $\begin{array}{l}18 \\
18 \\
18 \\
18 \\
15 \\
15 \\
15 \\
15 \\
13 \\
12 \\
12\end{array}$ & $\begin{array}{l}6 \\
6 \\
3 \\
6 \\
6 \\
7 \\
4 \\
3 \\
4 \\
6 \\
6\end{array}$ & $\begin{array}{l}70 \\
49 \\
42 \\
42 \\
36 \\
32 \\
45 \\
33 \\
26 \\
49 \\
37\end{array}$ & $\begin{array}{l}37 \\
20 \\
37 \\
32 \\
24 \\
32 \\
28 \\
32 \\
16 \\
44 \\
29\end{array}$ & $\begin{array}{r}6 \\
16 \\
6 \\
7 \\
0 \\
0 \\
8 \\
5 \\
9 \\
3\end{array}$ & $\begin{array}{r}1 \\
9 \\
9 \\
2 \\
0 \\
2 \\
1 \\
8 \\
-4\end{array}$ & $\begin{array}{l}3.4 \\
5.8 \\
5.5 \\
3.8 \\
7.9 \\
3.3 \\
9.4 \\
3.8 \\
5.9 \\
3.8 \\
4.6\end{array}$ & $\begin{array}{l}3.7 \\
4 \cdot 1 \\
5.0 \\
6.5 \\
9.5 \\
3.3 \\
6.6 \\
5.3 \\
4.6 \\
3.9 \\
4.5\end{array}$ & $\begin{array}{r}1,488 \\
453 \\
483 \\
768 \\
296 \\
785 \\
382 \\
525 \\
285 \\
847 \\
586\end{array}$ & $\begin{array}{l}770 \\
213 \\
451 \\
367 \\
143 \\
785 \\
313 \\
362 \\
263 \\
735 \\
586\end{array}$ & $\begin{array}{r}52 \\
47 \\
93 \\
48 \\
48 \\
100 \\
82 \\
69 \\
92 \\
87 \\
100\end{array}$ & $\begin{array}{l}71 \\
51 \\
59 \\
46 \\
54 \\
56 \\
65 \\
59 \\
59 \\
67 \\
48\end{array}$ & $\begin{array}{l}58 \\
46 \\
56 \\
38 \\
46 \\
49 \\
60 \\
56 \\
52 \\
63 \\
40\end{array}$ & $\begin{array}{l}39 \\
55 \\
36 \\
40 \\
46 \\
60 \\
42 \\
42 \\
37 \\
28\end{array}$ & $\begin{array}{l}28 \\
38 * \\
28 \\
30\end{array}$ \\
\hline
\end{tabular}

- After six weeks of treatment.

P.A.P. = Pulmonary arterial pressure.

P.W.P. = Pulmonary wedge pressure.
P.V.R. = Pulmonary vascular resistance.

P.V.R. = Pulmonary vascular resis.
P.C.V. = Packed cell volume.

TABLE III-Oxygen Uptake, Mean Pulmonary Arterial Pressure, Pulmonary Wedge Pressure, Cardiac Output, and Pulmonary Vascular Resistance during Exercise before and after Oxygen Therapy.

\begin{tabular}{|c|c|c|c|c|c|c|c|c|c|c|c|c|c|}
\hline \multirow{2}{*}{$\begin{array}{l}\text { Case } \\
\text { No. }\end{array}$} & \multirow{2}{*}{$\begin{array}{c}\text { Hours of } \\
\text { O/Day, }\end{array}$} & \multirow{2}{*}{$\begin{array}{c}\text { No. of } \\
\text { Weeks on } \\
\mathrm{O}_{2}\end{array}$} & \multicolumn{2}{|c|}{$\begin{array}{c}\text { Oxygen Uptake } \\
(\mathrm{ml} / \mathrm{min})\end{array}$} & \multicolumn{2}{|c|}{ P.A.P. (mmHg) } & \multicolumn{2}{|c|}{ P.W.P. $(\mathrm{mmHg})$} & \multicolumn{2}{|c|}{$\underset{(1 . / \mathrm{min})}{\text { Cardiac Output }}$} & \multicolumn{2}{|c|}{$\begin{array}{c}\text { P.V.R. } \\
\left(\text { dyn } / \mathrm{sec}^{\left.-\mathrm{cm}^{-s}\right)}\right.\end{array}$} & \multirow{2}{*}{\begin{tabular}{|l} 
P.V.R. After $\mathrm{O}_{2}$ \\
$\begin{array}{c}(\%) \\
\%\end{array}$
\end{tabular}} \\
\hline & & & $\begin{array}{c}\text { Before } \\
\mathrm{O}_{2}\end{array}$ & $\begin{array}{c}\text { After } \\
\mathrm{O}_{2}\end{array}$ & $\begin{array}{c}\text { Before } \\
\mathrm{O}_{2}\end{array}$ & $\begin{array}{l}\text { After } \\
\mathbf{O}_{\mathbf{y}}\end{array}$ & $\begin{array}{c}\text { Before } \\
\mathrm{O}_{2}\end{array}$ & $\begin{array}{c}\text { After } \\
\mathrm{O}_{2}\end{array}$ & $\begin{array}{c}\text { Before } \\
\mathrm{O}_{2}\end{array}$ & $\begin{array}{c}\text { After } \\
\mathrm{O}_{2}\end{array}$ & $\begin{array}{c}\text { Before } \\
\mathrm{O},\end{array}$ & $\begin{array}{c}\text { After } \\
\mathrm{O}_{\mathbf{3}}\end{array}$ & \\
\hline $\begin{array}{l}1 \\
2 \\
3 \\
4\end{array}$ & $\begin{array}{l}18 \\
18 \\
18 \\
18\end{array}$ & $\begin{array}{l}6 \\
6 \\
3 \\
6\end{array}$ & $\begin{array}{l}487 \\
581 \\
481\end{array}$ & $\begin{array}{l}609 \\
781 \\
496\end{array}$ & $\begin{array}{r}103 \\
56 \\
83\end{array}$ & $\begin{array}{l}80 \\
47 \\
56\end{array}$ & 16 & $\begin{array}{l}13 \\
20 \\
12\end{array}$ & $\begin{array}{l}4 \cdot 5 \\
9 \cdot 3 \\
7 \cdot 2\end{array}$ & $\begin{array}{l}6 \cdot 6 \\
7 \cdot 9 \\
5 \cdot 4\end{array}$ & $\begin{array}{r}1,563 \\
257 \\
792\end{array}$ & $\begin{array}{l}808 \\
272 \\
657\end{array}$ & $\begin{array}{r}51 \\
106 \\
83\end{array}$ \\
\hline $\begin{array}{r}5 \\
6 \\
7 \\
8 \\
9 \\
10 \\
11\end{array}$ & $\begin{array}{l}15 \\
15 \\
15 \\
15 \\
13 \\
12 \\
12\end{array}$ & $\begin{array}{l}6 \\
7 \\
4 \\
3 \\
4 \\
6 \\
6 \\
6\end{array}$ & $\begin{array}{l}625 \\
437 \\
800 \\
532 \\
682 \\
575 \\
504\end{array}$ & $\begin{array}{l}577 \\
457 \\
767 \\
615 \\
677 \\
825 \\
532\end{array}$ & $\begin{array}{l}52 \\
54 \\
76 \\
64 \\
41 \\
75 \\
52\end{array}$ & $\begin{array}{l}42 \\
51 \\
51 \\
50 \\
26 \\
73 \\
39\end{array}$ & $\begin{array}{r}10 \\
7 \\
10 \\
12 \\
17 \\
6\end{array}$ & $\begin{array}{r}5 \\
5 \\
11 \\
16 \\
1\end{array}$ & $\begin{array}{r}11 \cdot 4 \\
5.5 \\
11 \cdot 4 \\
5 \cdot 7 \\
9 \cdot 7 \\
4 \cdot 2 \\
6 \cdot 2\end{array}$ & $\begin{array}{r}12 \cdot 5 \\
7 \cdot 0 \\
11 \cdot 2 \\
6 \cdot 3 \\
8 \cdot 8 \\
7 \cdot 7 \\
6.5\end{array}$ & $\begin{array}{r}294 \\
687 \\
501 \\
758 \\
240 \\
1,104 \\
598\end{array}$ & $\begin{array}{l}204 \\
522 \\
327 \\
512 \\
137 \\
590 \\
467\end{array}$ & $\begin{array}{l}69 \\
76 \\
65 \\
68 \\
57 \\
53 \\
78\end{array}$ \\
\hline
\end{tabular}

P.A.P. = Pulmonary arterial pressure.

P.W.P. = Pulmonary wedge pressure.
P.V.R. = Pulmonary vascular resistance. 
and therefore the haemodynamic values during exercise were not always comparable. Generally, however, there was a lower pulmonary arterial pressure and pulmonary vascular resistance during steady-state exercise after the patient had undergone treatment with oxygen.

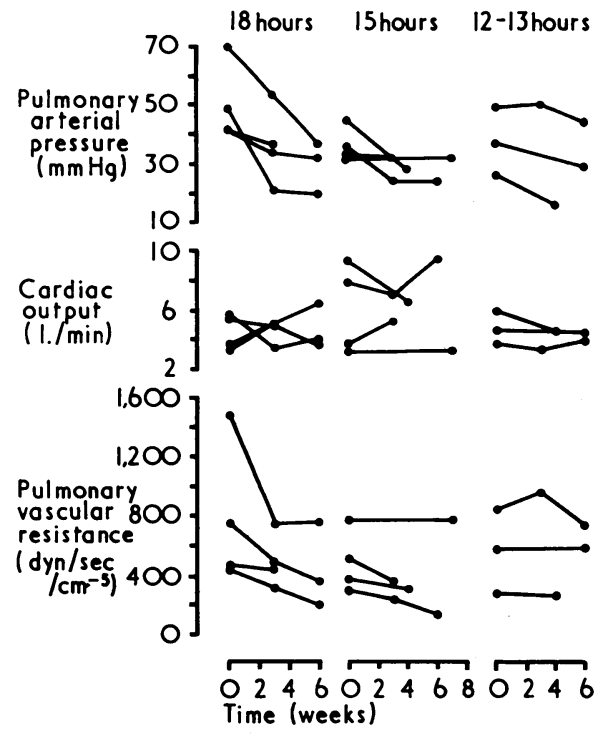
FIG. 1-Pulmonary arterial pressure, cardiac output, and pulmonary vascular
resistance before and three to seven weeks after treatment with oxygen for 18 hours, 15 hours, and 12-13 hours a day.

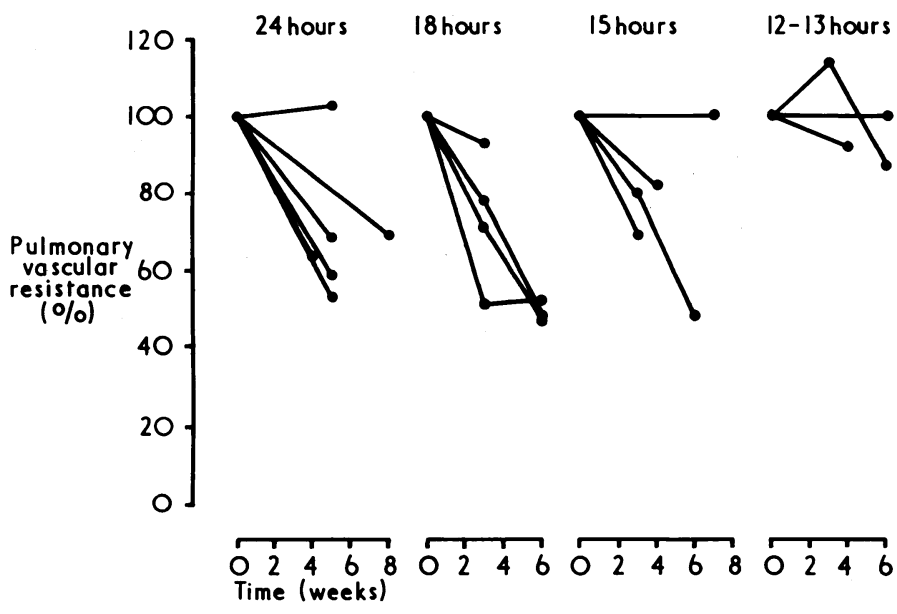

FIG. 2-Changes in pulmonary vascular resistance after treatment with oxygen for 24 hours (from Abraham et al., 1968), 18 hours, 15 hours, and 12-13 hours a day. Pulmonary vascular resistance after treatment is expressed as percentage of value for patient before treatment.

\section{OXYGEN ADMINISTRATION 15 HOURS DAILY}

In four patients haemodynamic studies were performed before and after three to seven weeks of oxygen therapy for 15 hours a day. In all patients there was a reduction in packed cell volume after oxygen therapy (Table II). The mean pulmonary arterial pressure decreased from 37 to $29 \mathrm{~mm} \mathrm{Hg}$, but the change was not statistically significant $(0 \cdot 1>P>0.05)$. Pulmonary vascular resistance decreased from 497 to $401 \mathrm{dyn} / \mathrm{sec} / \mathrm{cm}^{-5}$, and this was significant $(P<0.05)$. Study of the individual responses (Fig. 1 , Table II) showed that in Case 6 there was no response in spite of a seven-week period of oxygen therapy.

The pulmonary vascular resistance after treatment expressed as above is shown in Fig. 2. The patient in whom three studies were carried out continued to improve between the third and sixth weeks. In all four patients the pulmonary arterial pressure and pulmonary vascular resistance during exercise were lower after treatment with oxygen (Table III).
OXYGEN ADMINISTRATION 12-13 HOURS DAILY

Two patients received oxygen for 12 hours daily. A third patient was added who in spite of close supervision had failed to take oxygen for 15 hours daily as instructed and had "free periods" averaging two hours a day. So far as we are aware nonco-operation of this magnitude did not occur in any other patient. In all patients there was a decrease in packed cell volume but in one there was no change in red cell volume (Table II).

The haemodynamic responses were variable (Table II). In Case 9 the mean pulmonary arterial pressure decreased from 26 to $16 \mathrm{~mm} \mathrm{Hg}$, which is within the normal range; however, the pulmonary vascular resistance decreased by only $8 \%$. Comparison of the pulmonary arterial pressures and pulmonary vascular resistances during steady-state exercise was justifiable in this patient since the oxygen uptake on exercise, and hence the work performed, was the same before and after treatment. A sharp fall in pulmonary arterial pressure and pulmonary vascular resistance occurred (Table III). It seems likely that this patient had responded to treatment with oxygen for 13 hours a day although the pulmonary vascular resistance at rest had not decreased appreciably.

Case 10 showed little change in pulmonary arterial pressure and pulmonary vascular resistance measured at rest, but the studies during exercise showed that after treatment more exercise could be performed with a smaller rise in pulmonary vascular resistance.

In Case 11 there was little change in pulmonary vascular resistance either at rest or during exercise. The pulmonary arterial pressure at rest decreased but this was offset by a reduction in the pulmonary wedge pressure to $-4 \mathrm{~mm} \mathrm{Hg}$ which seemed unlikely physiologically but could not justifiably be eliminated.

For the group as a whole the decrease in pulmonary arterial pressure from a mean of 37 to $30 \mathrm{~mm} \mathrm{Hg}$ was statistically significant $(P<0.05)$ but the change in resistance was not significant. Figs. 1 and 2 show that the responses in this group were small.

\section{Discussion}

This study has shown the difficulties in expressing the responses of the pulmonary vascular bed. Pulmonary arterial pressure may be affected by changes in cardiac output - that is, pulmonary blood flow-as well as by changes in the calibre of the pulmonary vessels. Although cardiac output did not change significantly in any of the groups appreciable changes occurred in some individuals. It was possible to compensate for such changes in cardiac output by comparing pulmonary vascular resistance before and after treatment with oxygen, but this involves the assumption that pressure and flow are linearly related in the pulmonary vascular bed. In chronic bronchitics pressure-flow curves are convex to the pressure axis (Harris, Segel, and Bishop, 1968), and a sizeable increase in cardiac output would therefore cause passive distension of the pulmonary resistance vessels and a reduction in pulmonary vascular resistance. This may have contributed to the decrease in pulmonary vascular resistance in Case 10 during exercise when the cardiac output after oxygen therapy was almost twice the value before treatment. Similar effects may have occurred in other patients (Case 1 during exercise, Case 4 at rest), but generally the increase or decrease in cardiac output appeared too small to be of significance.

In some patients in whom oxygen therapy caused little decrease in pulmonary arterial pressure or resistance at rest the values for exercise suggested a response of the pulmonary circulation (Tables II and III). Thus the haemodynamic status during exercise was probably a more sensitive index of the response to therapy with oxygen and was of value, for example, in showing the response in Case 9, where the patient had a minimal change in pulmonary vascular resistance at rest. In several patients the usefulness of values during exercise was 
limited by differences in oxygen uptake during the two periods of exercise and in others-for instance, Case 10-by a large change in cardiac output (see above). Sime, Penaloza, and Ruiz (1971) showed that two years after normal subjects descended from high altitudes to sea level the pulmonary arterial pressure at rest had returned to normal values but the pulmonary arterial pressure during exercise remained raised. It seems that measurements during exercise provide the more sensitive index of reversal of pulmonary hypertension both at the early (Table III) and late stages (Sime et al., 1971).

The present study does not contain a control group but we have shown previously that patients who received otherwise identical hospital treatment and who unknowingly breathed air instead of oxygen did not show a decrease in the pulmonary hypertension over one to three weeks (Abraham et al., 1968). The same patients subsequently responded to continuous oxygen.

We have shown in this study that less than continuous oxygen caused partial reversal of pulmonary hypertension in patients with chronic bronchitis. Certain patients failed to respond to oxygen therapy regardless of the daily duration (Fig. 2). The characteristics of this group are not yet clear. In a study such as this, which involves small numbers of patients in each of the treatment groups, the presence of a single patient who fails to respond may lead to statistical insignificance for the whole group. In such circumstances study of the individual responses remains of great importance. Careful consideration of all the data led us to the following conclusions. Certain patients with chronic bronchitis do not undergo reversal of the pulmonary hypertension when treated with oxygen. In the remainder administration of oxygen for 18 hours and 15 hours a day leads to partial reversal of the pulmonary hypertension. The value of 12 hours of oxygen a day is not clear and requires further study.

This work has shown that the response to oxygen therapy may increase over a period of six weeks. It is not known how long the pulmonary arterial pressure will continue to decrease or at what pressure it will finally settle. Two patients now have normal pulmonary arterial pressures, one after four weeks and the other after six months of oxygen therapy (results to be published.)

In addition to the criteria already discussed most of the patients showed improvement in general health. None had an episode of congestive cardiac failure while on oxygen therapy, and this applies also to the three patients who continued oxygen therapy at home for periods up to one year. Two of these patients returned to full-time work, one of them after two years of chronic invalidism before therapy with oxygen. Petty and Finigan (1968) showed in patients with chronic bronchitis living in Denver that treatment with continuous oxygen for up to 25 months caused an increase in exercise tolerance and a decrease in the number of hospital admissions and of episodes of cardiac failure.
The reversal of pulmonary hypertension by oxygen is not permanent and the original state returns within several weeks of stopping oxygen (Abraham et al., 1968). This is consistent with the report by Ude and Howard (1971) that long-term survival was not prolonged by administration of oxygen for the duration of exacerbations but not in the periods between exacerbations.

The maximal alveolar oxygen tension likely to occur during oxygen therapy in patients with severe obstructive airways disease is lower than the levels which have been shown to cause lung damage in man (Clark and Lambertsen, 1971). No evidence of oxygen toxicity to the lung has been found in the present study, but the possibility will be kept under review.

We intend to continue the study and to concentrate on returning patients to their homes on long-term oxygen therapy. The 18-hour regimen would involve considerable restriction of activity and might possibly lead to poor co-operation by the patient. The 15-hour regimen of oxygen treatment is promising since this can be undertaken in the evenings and through the night. The remaining nine hours free from an oxygen supply are consistent with a working day.

We gratefully acknowledge the help given by all who work in the department of medicine, without which this study would not have been possible. In particular we are grateful to Dr. M. Meynell for determination of the red cell volumes, and to Staff nurse M. Booth, Miss J. Blackhall, Miss F. Langley, Mrs. S. Gillett, Mrs. J. Taylor, and Mr. J. Milton for technical help. A number of consultants kindly referred patients to our care, and Dr. R. Joshi helped during some of the studies. The work was supported by a grant from the British Heart Foundation.

\section{References}

Abraham, A. S., Cole, R. B., and Bishop, J. M. (1968). Circulation Research, 23, 147.

Abraham, A. S., et al. (1969). Circulation Research, 24, 51.

Abraham, A. S., Kay, J. M., Cole, R. B., and Pincock, A. C. (1971). Cardiovascular Research, 5, 95.

Clark, J. M., and Lambertsen, C. J. (1971). Pharmacological Reviews, 23, 37. Green, I. D. (1967). British Medical fournal, 3, 593.

Harris, P., Segel, N., and Bishop, J. M. (1968). Cardiovascular Research, 2, 73.

Hasleton, P. S., Heath, D., and Brewer, D. B. (1968). Fournal of Pathology and Bacteriology, $95,431$.

Hicken, P., Heath, D., Brewer, D. B., and Whitaker, W. (1965). Journal of Pathology and Bacteriology, 90, 107.

Levine, B. E., et al. (1967). Annals of Internal Medicine, 66, 639.

Petty, T. L., and Finigan, M. M. (1968). American fournal of Medicine, 45, 242 .

Renzetti, A. D., McClement, J. H., and Litt, B. D. (1966). American fournal of Medicine, 41, 115 .

Sime, F., Penaloza, D., and Ruiz, L. (1971). British Heart fournal, 33, 647. Stuart-Harris, C. H., and Hanley, T. (1957). Chronic Bronchitis, Emphysema and Cor Pulmonale. Bristol, Wright.

Ude, A. C., and Howard, P. (1971). Thorax, 26, 572. 